\title{
Propagation of coffee conilon "Vitória" in conventional and alternative substrates
}

\author{
Sávio da Silva Berilli1 (iD), Rodrigo Amaro de Salles ${ }^{2}$ (D), Ramon Amaro de Sales ${ }^{3}$ (D), Alan Alvino Falcão Zooca ${ }^{4}$ (D), \\ Helder Rodrigues Ribeiro ${ }^{4}$ (D), Ana Paula Candido Gabriel Berilli1 (iD), Taiara Souza Costa ${ }^{3}$ (D), \\ Tiago Pacheco Mendes ${ }^{2}$ (D), Waylson Zancanella Quartezani ${ }^{5}$ (i)
}

${ }^{1}$ Instituto Federal do Espírito Santo/IFES, Alegre, ES, Brasil

${ }^{2}$ Universidade Federal do Espírito Santo/UFES, Alegre, ES, Brasil

${ }^{3}$ Universidade Federal de Viçosa/UFV, Viçosa, MG, Brasil

${ }^{4}$ Instituto Federal do Espírito Santo/IFES, Colatina, ES, Brasil

${ }^{5}$ Instituto Federal do Espírito Santo/IFES, Montanha, ES, Brasil

Contact authors: berilli@gmail.com, rodrigoamarodesalles@gmail.com, ramonamarodesales@hotmail.com, alan_afz@hotmail.com, helder_pancas@hotmail.com, anapaulacg@ gmail.com, taiiarauefs@gmail.com, tiagopm931@hotmail.com, waylson.quartezani@ifes.edu.br

Received in March 17, 2020 and approved in May 26, 2020

\section{ABSTRACT}

The sustainable production of inputs or products, either agricultural or industrial, has become an international concern in the last years. Thus, one of the biggest challenges today is to combine production with sustainability. Industrial waste use in agriculture is an alternative that has been gaining strength. The objective of this study was to evaluate the development, physiology and quality of Coffea canephora seedlings from the 13 genotypes (variety Vitória Incaper 8142), in conventional substrate in comparison to a substrate based on tannery sludge. A $2 \times 13$ factorial scheme was used in which the first factor was the two substrates (conventional substrate and substrate with tannery sludge), and the second factor was the 13 Vitória - Incaper 8142 Conilon coffee genotypes, arranged in a randomized block design with four repetitions. At 150 days after planting, the following characteristics were evaluated: leaf number, plant height, stem diameter, canopy diameter, leaf area, SPAD chlorophyll index, nitrogen balance index, total chlorophyll index, anthocyanins index and flavonoids index, dry shoot matter mass, dry root matter mass, dry total matter mass and Dickson quality index. No significant interaction was observed between the factors evaluated. The substrate containing tannery sludge provided less gain for most of the growth characteristics when compared to the conventional substrate. The tannery substrate promoted a greater production of defense metabolites in plants. As for the response pattern between the genotypes of the Vitória - Incaper 8142 variety, a high unevenness was observed in the initial development, both for their phenological and physiological characteristics, which is a reflect of the genetic variability existing between the genotypes.

Key words: Seedling production; Coffe canephora; physiology; sustenaibility.

\section{INTRODUCTION}

Coffee is a drink immensely appreciated by a large part of the world's population, so to meet this demand, estimates indicate that the harvest in 2019-2020 will be 167.4 million bags benefited from $60 \mathrm{~kg}$, with $42.8 \%$ of this total corresponding to the species Coffea canephora (International Coffee Organization - ICO, 2019). This percentage represents 71.72 million bags of $C$. canephora, $1.5 \%$ more than the previous harvest.

Although the species Coffea arabica is the most cultivated in Brazil, the species $C$. canephora has contributed significantly to the increase in the national production. The species $C$. canephora occupies a cropped area of approximately 400 thousand hectares and represents about $25 \%$ of the national production (Companhia Nacional de Abastecimento - CONAB, 2020).

Espírito Santo is a Brazilian state notably focused on coffee farming, mainly for the species C. canephora, contributing to approximately $76 \%$ of all the Brazilian production. Therefore, it is the largest producer in the country (Instituto Capixaba de Pesquisa Assistência Técnica e Extensão Rural - INCAPER, 2019). However, despite the high productivity, the cost of producing this crop is still high, so there is a need to prioritize techniques that aim to reduce such costs.

In the coffee seedling production sector, studies were carried out with the objective of reducing production costs, such as the use of tannery sludge, urban compost, dairy waste and coffee drying residue as a source of organic matter, or even as foliar fertilization, becoming a very important alternative (Meneghelli et al., 2016; Sales et al., 2018a; Quartezani et al., 2019). With regard to tannery sludge, this residue from bovine leather processing has a high potential for agricultural use, due to the large amount of organic matter and the presence of essential nutrients to the plants found in it (Tavares et al., 2013; Berilli et al., 2018; Vazifehkhoran; Shin; Triolo, 2018).

However, the tanneries are known for the high load of pollutants that are generated during leather processing and for the environmental impacts that the inappropriate disposal of these residues represents (Silva et al., 2010a; Alibardi; Cossu, 2016). As a result, the use of tannery residue in the propagation of Conilon coffee seedlings, mainly on substrates, can help to 
reduce production costs and, at the same time, contribute to an appropriate purpose when used properly.

Plant development is directly affected by the quality of the substrate, as it is responsible for supporting the plants while providing water and nutrients. Recent studies indicate that the use of tannery sludge in substrates for the production of conilon coffee seedlings had positive effects, guaranteeing development standards acceptable to planting (Berilli et al., 2014; Quartezani et al., 2018).

Nevertheless, most of these studies are performed for only one genotype, and this species has numerous genotypes, which in turn, exhibit a completely different behavior in relation to several morphological and physiological characteristics (Giles et al., 2019). Thus, when proposing a new substrate for the propagation of this species, it is of great importance to know the behavior of the several genotypes.

Because of the high potential for agricultural use of tannery sludge, and the need for these industries to become more sustainable, the objective of this study was to evaluate the development, physiology and quality of $C$. canephora seedlings from the 13 genotypes (variety Vitória Incaper 8142 ), in conventional substrate in comparison to a substrate based on tannery sludge.

\section{MATERIAL AND METHODS}

The experiment was carried out in the seedling propagation nursery owned by the Federal Institute of Education, Science and Technology of Espírito Santo, Itapina campus, located in the city of Colatina, state of Espirito Santo, Brazil (19³2’22” S, 40³7'50'W at 71 above sea level). The climate in the region is Tropical Aw, according to the climate classification of Köppen, with a well-defined rainy season between October and January and an average rainfall of 1029.9 mm (Sales et al., 2018b). A 2 x 13 factorial scheme was used, where the first factor was two substrates (conventional substrate and substrate with tannery sludge), and the second factor was the 13 Conilon coffee genotypes. The treatments were arranged in a randomized block design with four replications. Each plot contained seven seedlings totaling 182 plants per block, and 728 plants throughout the experiment.

The two substrates were prepared 30 days in advance, in the following composition: substrate with sludge: $20 \%$ dehydrated tannery sludge $+30 \%$ humus and 50\% soil. Conventional substrate: $80 \%$ of soil and $20 \%$ of humus, and for each 100 liters of substrate, $0.625 \mathrm{~kg}$ of $\mathrm{P}_{2} \mathrm{O}_{5}, 0.200$ $\mathrm{kg}$ of limestone and $0.200 \mathrm{~kg}$ of $\mathrm{KCl}$ were added. After the homogenization of the components, the $600 \mathrm{~mL}$ polyethylene bags were filled and the beds were formed. Also, the substrate remained under irrigation until planting.

The soil used in the substrate was removed from the subsoil and classified as a Red Dystrophic Oxisol (Empresa
Brasileira de Pesquisa Agropecuária - EMBRAPA, 2013), with the following chemical characteristics: $\mathrm{pH}$ : 5.30; $\mathrm{P}$ : $4.00 \mathrm{e}^{-6} \mathrm{~kg} \mathrm{dm}^{-3} ; \mathrm{K}: 5.20 \mathrm{e}^{-5} \mathrm{~kg} \mathrm{dm}^{-3}$; remaining P: $2.00 \mathrm{e}^{-5} \mathrm{~kg} \mathrm{~mL}^{-1}$; Ca: 11.60 mmol $_{\mathrm{c}} \mathrm{dm}^{-3}$; $\mathrm{Mg}$ : $9.30 \mathrm{mmol}_{\mathrm{c}} \mathrm{dm}^{-3}$; $\mathrm{Al}: 0.50 \mathrm{mmol}_{\mathrm{c}} \mathrm{dm}^{-3}$; potential acidity $(\mathrm{H}+\mathrm{Al}): 14.00 \mathrm{mmol}_{\mathrm{c}} \mathrm{dm}^{-3}$; organic matter: $1.50 \mathrm{e}^{-3} \mathrm{~kg} \mathrm{dm}^{-3}$; sum of bases (SB): $22.20 \mathrm{mmol}_{\mathrm{c}} \mathrm{dm}^{-3}$; cation exchange capacity (CEC) at $\mathrm{pH} 7$ (T): $36.20 \mathrm{mmol}_{\mathrm{c}} \mathrm{dm}^{-3}$; effective CEC ( $\mathrm{t}$ ): $22.70 \mathrm{mmol}_{\mathrm{c}} \mathrm{dm}^{-3}$; Al saturation $(\mathrm{m}): 2.20 \%$ and base saturation: $61.40 \%$.

The tannery sludge used in the experiment was provided by the company Capixaba Couros LTDA, located in the municipality of Baixo Guandu, ES. The sludge, together with the humus, were submitted to laboratory analysis to obtain the chemical parameters (Table 1).

Table 1: Chemical characteristics of the organic material used in the substrate.

\begin{tabular}{cclc}
\hline Parameter & Unit & Sludge & Humus \\
\hline Total Organic matter & $\mathrm{kg} \mathrm{dm}^{-3}$ & $0.30 *$ & $4.63 \mathrm{e}^{-2}$ \\
Organic Carbon & $\mathrm{g} \mathrm{kg}^{-1}$ & 61.2 & 201.90 \\
C/N ratio & - & $3 / 1$ & $10 / 1$ \\
$\mathrm{~N}$ & $\mathrm{~kg} \mathrm{dm}^{-3}$ & $1.73 \mathrm{e}^{-2}$ & $2.10 \mathrm{e}^{-2}$ \\
$\mathrm{P}$ & $\mathrm{kg} \mathrm{dm}^{-3}$ & $5.20 \mathrm{e}^{-3}$ & $1.19 \mathrm{e}^{-2}$ \\
$\mathrm{~K}$ & $\mathrm{~kg} \mathrm{dm}^{-3}$ & $6.00 \mathrm{e}^{-4}$ & $7.50 \mathrm{e}^{-3}$ \\
$\mathrm{Ca}$ & $\mathrm{kg} \mathrm{dm}^{-3}$ & 0.23 & $2.18 \mathrm{e}^{-2}$ \\
$\mathrm{Mg}$ & $\mathrm{kg} \mathrm{dm}^{-3}$ & $1.53 \mathrm{e}^{-2}$ & $5.40 \mathrm{e}^{-3}$ \\
$\mathrm{~S}$ & $\mathrm{~kg} \mathrm{dm}^{-3}$ & $1.32 \mathrm{e}^{-2}$ & $4.50 \mathrm{e}^{-3}$ \\
$\mathrm{Na}$ & $\mathrm{kg} \mathrm{dm}^{-3}$ & $5.50 \mathrm{e}^{-3}$ & $3.70 \mathrm{e}^{-3}$ \\
$\mathrm{Cl}$ & $\mathrm{kg} \mathrm{dm}^{-3}$ & $3.70 \mathrm{e}^{-2}$ & $2.00 \mathrm{e}^{-5}$ \\
$\mathrm{~B}$ & $\mathrm{~kg} \mathrm{dm}^{-3}$ & $3.00 \mathrm{e}^{-4}$ & $2.00 \mathrm{e}^{-5}$ \\
\hline
\end{tabular}

${ }^{*}$ Results on dry matter basis (mass/mass).

The Conilon coffee ( $C$. canephora Pierre) seedlings used in the experiment were of "Vitória Incaper 8142" clonal variety (13 genotypes), produced at the Institute itself, from cuttings obtained from adult tissue from orthotropic stem taken from crops with an adequate phytosanitary and nutritional aspect. After removing the branches from the mother plants, they were sent to the greenhouse, where $0.3 \mathrm{~m}$ of the ends of the orthotropic stems were eliminated. Then, the cuttings were standardized at 0.06 to $0.08 \mathrm{~m}$ in height, leaves with $1 / 3$ of the leaf blade, plagiotropic branches and above the insertion of the pair of leaves with $0,01 \mathrm{~m}$ (Ferrão et al., 2017). The cuttings were planted as soon as they were ready on a previously moistened substrate.

The seedlings of conventional and tannery sludge substrates were submitted to foliar fertilization (three applications) with nitrogen and potassium, being considered a dosage of $3.00 \mathrm{e}^{-4} \mathrm{~kg}$ of urea and $3.00 \mathrm{e}^{-4} \mathrm{~kg}$ of $\mathrm{KCl}$ completed 
to $100 \mathrm{~mL}$ of water with the two elements, which corresponds to $1.35 \mathrm{e}^{-3} \mathrm{~kg} \mathrm{~L}^{-1} \mathrm{~N}$ and $1.8 \mathrm{e}^{-3} \mathrm{~kg} \mathrm{~L}^{-1} \mathrm{~K}_{2} \mathrm{O}$. The first application occurred shortly after the appearance of the second pair of leaves followed by the next spaced every 30 days. The irrigations were carried out by the aspertion method, and the system was turned on for 20 seconds at intervals of 30 minutes. No phytosanitary control was required during the conduct of the experiment.

The leaf number (LN), plant height (PH), stem diameter (SD), canopy diameter $(\mathrm{CaD})$, leaf area (LA) measured using the LI-3100C instrument, the leaf chlorophyll index measured by means of SPAD-502-PLUS were evaluated at 150 days. Assessments of dry shoot matter mass (DSMm), dry root matter mass (DRM $m$ ) and dry total matter mass (DTM $m$ ) were evaluated were evaluated. The dry matter mass was obtained by incubating the material in a forced circulation oven at $72{ }^{\circ} \mathrm{C}$ for $72 \mathrm{~h}$, and then weighing it on a precision analytical scale. After obtaining these data, the Dickson Quality Index (DQI) was calculated using the Equation 1:

$$
D Q I=\frac{D T M m}{\left(\left(\frac{P H}{S D}\right)+\left(\frac{D S M m}{D R M m}\right)\right)}
$$

Besides the SPAD, analyses of the plant physiology were performed using a multiplex ${ }^{\circledR}$ fluorometer model (Force-A), with multiple sources of light excitation, estimating index of various compounds, such as nitrogen balance (NBIR), total chlorophyll (SFRR), anthocyanins (ANTHRB) and flavonoids (FLAV). The analyses were carried out in the morning, between 9 and 11 a.m. and on only one side of the seedlings, pointing the equipment towards canopy, from top to bottom, at an angle of approximately 45 degrees.

The data were subjected to analysis of variance, using the F test and when significant, subjected to the Scott-Knott test at a significance level of 5\% probability with the aid of the R software (R Core Team, 2016), using the package "ExpDes. pt" (Ferreira; Cavalcanti; Nogueira, 2013). Correlation tests between variables were also performed using Pearson's correlation coefficient (r), using the "corrplot" package (Wei; Simko, 2017).

\section{RESULTS AND DISCUSSION}

The V3 genotype was not analyzed statistically due to the low rate of seedling survival, which did not reach $20 \%$. This genotype is known by many seedling producers as a genotype that is difficult to propagate, and this characteristic is inherent in the genetic material itself.

No occurred interaction among the factors studied (substrate $\mathrm{x}$ genotypes) for all the evaluated characteristics in Conilon coffee seedlings of the variety "Vitória - Incaper 8142 " (Table 2). Therefore, the simple effects of the factors were evaluated on the growth and physiological characteristics of seedling.

Table 2: Analysis of variance of plant height (PH), stem diameter (SD), canopy diameter (CaD), leaf area (LA), dry shoot matter mass (DSMm), root (DRMm) and total (DTMm), leaf number (LN), Dickson quality index (DQI) leaf chlorophyll index (SPAD), total chlorophyll (SFRR), nitrogen balance (NBIR), anthocyanin index (ANTHRB) and flavonoid index (FLAV) in Conilon coffee seedlings.

\begin{tabular}{|c|c|c|c|c|c|c|c|c|}
\hline \multirow{2}{*}{ SV } & \multirow{2}{*}{$\mathrm{DF}$} & \multicolumn{7}{|c|}{ Mean Square } \\
\hline & & PH (m) & $\mathrm{SD}(\mathrm{m})$ & $\mathrm{CaD}(\mathrm{m})$ & $\mathrm{LA}\left(\mathrm{m}^{2}\right)$ & $\mathrm{DSM} m(\mathrm{~kg})$ & $\mathrm{DRM} m(\mathrm{~kg})$ & $\mathrm{DTM} m(\mathrm{~kg})$ \\
\hline Substrate (S) & 1 & $5.02 * *$ & $3.40 \mathrm{e}^{-4} \mathrm{~ns}$ & $0.30 \mathrm{~ns}$ & $2,39 *$ & $1.21 \mathrm{e}^{-2 * * * *}$ & $6.00 \mathrm{e}^{-7} \mathrm{~ns}$ & $0.12 * *$ \\
\hline Genotypes $(\mathrm{G})(\mathrm{C})$ & 11 & $0.21 * *$ & $8.00 \mathrm{e}^{-4 * *}$ & $0.38 * *$ & $1,05 * *$ & $3.60 \mathrm{e}^{-3 * *}$ & $2.10 \mathrm{e}^{-4 * *}$ & $5.30 \mathrm{e}^{-3 * *}$ \\
\hline $\mathrm{SxG}$ & 11 & $0.13 \mathrm{~ns}$ & $1.90 \mathrm{e}^{-4} \mathrm{~ns}$ & $0.06 \mathrm{~ns}$ & $0.65 \mathrm{~ns}$ & $8.50 \mathrm{e}^{-4} \mathrm{~ns}$ & $6.00 \mathrm{e}^{-5} \mathrm{~ns}$ & $1.00 \mathrm{e}^{-3} \mathrm{~ns}$ \\
\hline Residue & 69 & 0.08 & $2.20 \mathrm{e}^{-4}$ & 0.08 & 0.40 & $9.00 \mathrm{e}^{-4}$ & $5.00 \mathrm{e}^{-5}$ & $1.20 \mathrm{e}^{-3}$ \\
\hline Overall mean & & 0.17 & $3.99 \mathrm{e}^{-3}$ & 0.20 & 0.26 & $3.86 \mathrm{e}^{-3}$ & $8.10 \mathrm{e}^{-4}$ & $4.80 \mathrm{e}^{-3}$ \\
\hline CV $(\%)$ & & 16.51 & 11.36 & 13.88 & 24.50 & 24.55 & 26.91 & 23.20 \\
\hline SV & DF & LN & DQI & SPAD & SFRR & FLAV & ANTHRB & NBIR \\
\hline Substrate (S) & 1 & $40.07 * *$ & $3.00 \mathrm{e}^{-3} \mathrm{~ns}$ & $210.63 * *$ & $0.15 \mathrm{~ns}$ & $0.13 * *$ & $0.0005 \mathrm{~ns}$ & $5.35 *$ \\
\hline Genotypes $(\mathrm{G})(\mathrm{C})$ & 11 & $7.61 *$ & $0.07 * *$ & $131.61 * *$ & $0.31 \mathrm{~ns}$ & $0.07 * *$ & $0.0004 \mathrm{~ns}$ & $1.80 *$ \\
\hline $\mathrm{SxG}$ & 11 & $2.12 \mathrm{~ns}$ & $0.01 \mathrm{~ns}$ & $25.07 \mathrm{~ns}$ & $0.17 \mathrm{~ns}$ & $0.0080 \mathrm{~ns}$ & $0.0009 \mathrm{~ns}$ & $0.40 \mathrm{~ns}$ \\
\hline Residue & 69 & 4.20 & 0.02 & 15.71 & 0.21 & 0.005 & 0.0007 & 0.42 \\
\hline Overall mean & & 9.82 & 0.51 & 33.42 & 2.84 & 0.27 & 0.05 & 2.74 \\
\hline $\mathrm{CV}(\%)$ & & 19.65 & 26.07 & 11.86 & 16.21 & 27.19 & 26.95 & 25.29 \\
\hline
\end{tabular}

*Significant at $5 \%$ probability $(p<0.05)$; ${ }^{*}$ Significant at $1 \%$ probability $(p<0.01)$; ns: not significant. SV: Source of variation. DF: degrees of freedom. CV: coefficient of variation. 
Significant effect it was observed in the levels of the genotype factor for most of the evaluated characteristics (Table 2). Such results reveal inequalities in the initial growth of the genotypes. These genotopes have distinct genetic characteristics, which in turn results in considerable differences in most plant growth characteristics, indicating uneven growth within the variety (Covre et al., 2013). As for the levels of the substrate factor, it was not possible to observe a significant effect for most of the variables analyzed, including the seedling quality index, showing that the alternative substrate can provide seedlings with the same quality as the Conventional substrate used by producers.

It was observed that the different substrates caused significant effects on plant growth variables, with the exception of only stem diameter and canopy diameter (Table 3). The Conventional substrate provided higher averages for plant height, leaf number and leaf area, which were higher by 30 , 14 and $13 \%$ respectively, when compared to the substrate containing tannery sludge.

Although the canopy diameter variable did not show any difference (Table 3), the plants grown on conventional substrate obtained a higher leaf emission, which resulted in a larger leaf area, favored the carbon balance, which can be used for height gains and dry matter (Table 4). The plant height is one of the main characteristics observed by producers of conilon coffee seedlings, for determining the point of sale (Berilli et al., 2014). However, although the Conventional substrate had a higher height, the values found by the alternative substrate showed considerable growth in this experiment, reaching an average height of $0.15 \mathrm{~m}$.

Table 3: Plant height $(\mathrm{PH})$, stem diameter (SD), canopy diameter $(\mathrm{CaD})$, leaf number $(\mathrm{LN})$, leaf area $(\mathrm{LA})$, of "Vitória Incaper 8142" Conilon coffee plant, grown in two substrates.

\begin{tabular}{cccccc}
\hline Substrates & PH $(\mathrm{m})$ & $\mathrm{SD}(\mathrm{m})$ & $\mathrm{CaD}(\mathrm{m})$ & $\mathrm{LN}$ & $\mathrm{LA}\left(\mathrm{m}^{2}\right)$ \\
\hline Conventional & $0.19 \mathrm{a}$ & $4.14 \mathrm{e}^{-3} \mathrm{a}$ & $0.21 \mathrm{a}$ & $10.46 \mathrm{a}$ & $2.74 \mathrm{e}^{-2} \mathrm{a}$ \\
Sludge & $0.15 \mathrm{~b}$ & $4.02 \mathrm{e}^{-3} \mathrm{a}$ & $0.19 \mathrm{a}$ & $9.17 \mathrm{~b}$ & $2.42 \mathrm{e}^{-2} \mathrm{~b}$ \\
\hline
\end{tabular}

Means followed by the same letter in the column are not different from each other at the $5 \%$ probability level $(p<0.05)$ by the Scott-Knott test.

It is possible that these less favorable results for the substrate with tannery sludge are linked to the elements chromium and sodium, which are found in high amounts in this residue (Table 1). These elements can be absorbed by the roots and accumulated there and stem and leaves as well (Berilli et al., 2015), thus being able to cause some physiological disturbances and impairing the normal growth of the plant. However, it is worth mentioning that the sludge substrate did not receive any chemical fertilization, unlike the conventional substrate, which possibly resulted in a higher nutrient load readily available for absorption, enabling the best initial development (Tables 3 and 4).
Table 4: Dry shoot matter mass (DSMm), root (DRMm) and total (DTMm), Dickson squality index (DQI) and chlorophyll index (SPAD) of conilon coffee seedlings of the variety "Vitória Incaper 8142", grown on two substrates.

\begin{tabular}{cccccc}
\hline Substrates & $\begin{array}{c}\mathrm{DSM} m \\
(\mathrm{~kg})\end{array}$ & $\begin{array}{c}\mathrm{DRM} m \\
(\mathrm{~kg})\end{array}$ & $\begin{array}{c}\text { DTM } m \\
(\mathrm{~kg})\end{array}$ & DQI & SPAD \\
\hline Conventional & $4.21 \mathrm{e}^{-3} \mathrm{a}$ & $8.1 \mathrm{e}^{-4} \mathrm{a}$ & $5.02 \mathrm{e}^{-3} \mathrm{a}$ & $0.51 \mathrm{a}$ & $34.90 \mathrm{a}$ \\
Sludge & $3.50 \mathrm{e}^{-3} \mathrm{~b}$ & $8.2 \mathrm{e}^{-4} \mathrm{a}$ & $4.31 \mathrm{e}^{-3} \mathrm{~b}$ & $0.52 \mathrm{a}$ & $31.94 \mathrm{~b}$ \\
\hline
\end{tabular}

Means followed by the same letter in the column are not different from each other at the $5 \%$ probability level $(p<0.05)$ by the Scott-Knott test.

Greater gains were observed for the dry matter of the shoot and total of the plants grown on the conventional substrate (Table 4). Possibly, this result was obtained, due to the greater load of mineral nutrients readily available for abosrão, such as $\mathrm{P}$ and $\mathrm{K}$ found in the conventional substrate, result of the chemical fertilization that was incorporated in this substrate. These nutrients are fundamental to the development of plants, being directly part of plant metabolism (Marschner, 2011)

The nutrient $\mathrm{P}$, for example, plays a fundamental role in processes involving energy storage, having a central role in all reactions involving ATP, whether in respiration or in photosynthesis. The $\mathrm{K}$ element acts as a catalyst and plays a significant role in the activation of enzymes involved in photosynthetic activities (Zaheer et al., 2018). Thus, the greater availability of these nutrients in the conventional substrate, contributed strongly to improve the performance and metabolic regulation of these plants.

In addition, the conventional substrate also provided a higher SPAD index (Table 4), which acting in conjunction with a larger leaf area (Table 3), certainly increased the photosynthetic levels of the plants resulting in significant gains in fixing carbon, consequently higher dry matter content of the shoot and total (Silva et al., 2010b). This can be confirmed in Figure 1 by the strong positive correlation between total dry matter and leaf area $(r=0.75)$.

In general, the lower performance of plants grown on substrate with tannery sludge in highlighting the variables plant height, leaf number, leaf area (Table 3), chlorophyll index SPAD, dry shoot matter and dry total matter (Table 4), may have been in response to the salinity caused by $\mathrm{Na}$. Studies indicate that excess $\mathrm{Na}$ is responsible for causing negative effects in various vegetable species, including in conilon coffee (Carvalho et al., 2012; Temoteo et al., 2015). In coffee seedlings, salinity is responsible for decreasing the activity of the nitrate reductase enzyme, in addition to causing stomatal closure and drop in photosynthesis, which in turn, reflects in the lower growth rate (Karasawa et al., 2003).

The substrates did not promote any difference in terms dry root matter (Table 4). This indicates that the substrate with tannery sludge did not reveal any physical or chemical barriers, 
which would inhibit the root growth of the plants, and possibly was able to promote an environment similar to the conventional substrate, which resulted in a good root development. Conilon coffee seedlings with well-developed roots is an important aspect to be considered, as it is a factor that compromises the longevity of coffee plantations (Ferrão et al., 2017).

The nitrogen balance and the flavonoid index differed, being the inverse, that is, higher levels of flavonoids were followed by a lower nitrogen balance in plants grown on substrate with tannery sludge (Table 5). However, plants grown on conventional substrate obtained higher levels of nitrogen balance and lower levels of flavonoids.

These results can be better understood, since there is competition in the biosynthesis and metabolic regulation of

Table 5: Chlorophyll (SFRR), nitrogen balance (NBIR), flavonoids (FLAV) and anthocyanins (ANTHRB) in variety "Vitória Incaper 8142" Conilon coffee seedlings, grown on two substrates.

\begin{tabular}{ccccc}
\hline Substrates & SFRR & FLAV & NBIR & ANTHRB \\
\hline Conventional & $2.88 \mathrm{a}$ & $0.23 \mathrm{~b}$ & $2.73 \mathrm{a}$ & $0.032 \mathrm{a}$ \\
Sludge & $2.80 \mathrm{a}$ & $0.30 \mathrm{a}$ & $2.42 \mathrm{~b}$ & $0.031 \mathrm{a}$ \\
\hline
\end{tabular}

Means followed by the same letter in the column are not different from each other at $5 \%$ probability level $(p<0.05)$ by the test of Scott-Knott.

polyphenols and proteins, which use the same precursor, the amino acid phenylalanine (Coelho et al., 2012). Thus, due to the greater growth of plants grown on Conventional substrate, protein synthesis reduced the availability of phenylalanine to be used in phenolic synthesis (Caretto et al., 2015), which resulted in a lower rate of secondary compounds, such as flavonoids. For this reason, the physiological variables nitrogen balance and flavonoids have a negative correlation of $\mathrm{r}=-0.81$ (Figure 1).

Therefore, it is evident that the tannery sludge provided them with a greater synthesis of defense compounds. This, in turn, may be related to potentially toxic elements ( $\mathrm{Na}$ and $\mathrm{Cr}$ ) found in tannery residue, in addition to the low supply of $\mathrm{P}$ and the high $\mathrm{pH}$ found in the substrate with tannery (Table 1). The main functions of flavonoids are linked to the protection of plants against stress, either of biotic or abiotic origin (Khalid et al., 2019). The nitrogen balance index was higher in the conventional substrate and, possibly, this was one of the factors that contributed to leaf growth and expansion, since nitrogen participates in the composition of amino acids, proteins and chlorophylls.

For the growth variables between the genotypes (Table 6), only the leaf number did not difference, which highlights the unevenness in the initial development of the genotypes, which is a result of the genetic diversity in the variety. For plant height, the genotypes V2, V7, V8, V10 and $\mathrm{V} 11$ obtained the highest means ranging from 0.17 to $0.20 \mathrm{~m}$.
Regarding the stem diameter, the V8 genotype stands out with the best mean, which is superior to all the others. Contarato et al. (2010) also detected divergence in the initial development of genotypes of this variety, attributing the difference to the distinct genetic characteristics between the genotypes.

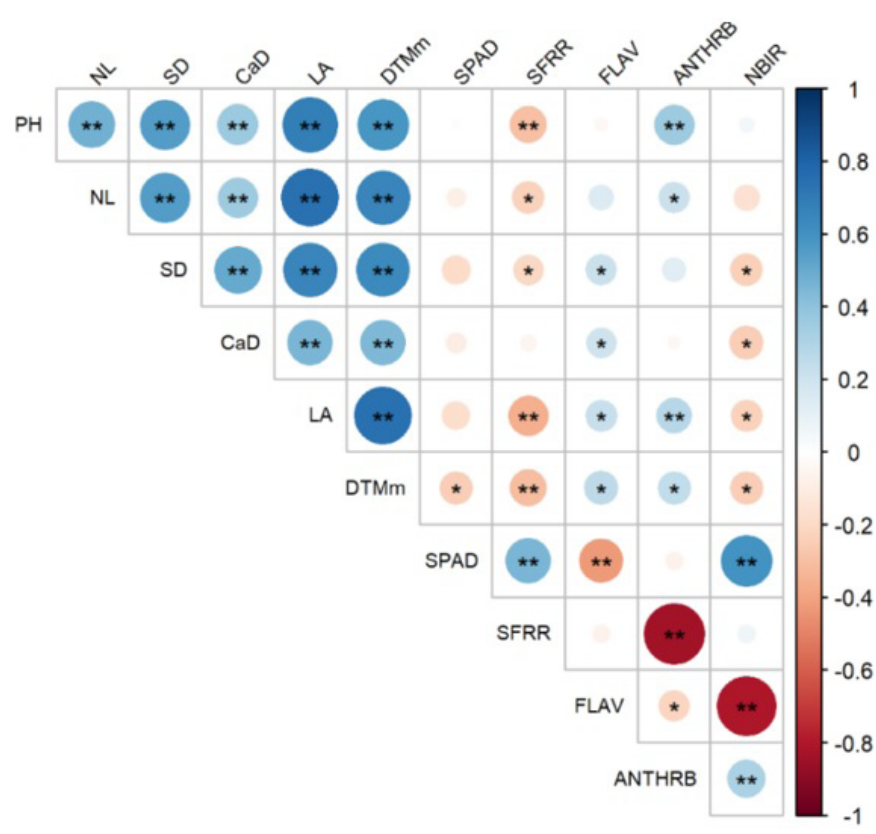

Figure 1: Association (Pearson correlation) between the main evaluated variables. Significant at ${ }^{*} p<0.05$; ${ }^{* *} p<0.01$. Plant height $(\mathrm{PH})$, stem diameter (SD), canopy diameter (CaD), leaf area (LA), dry matter mass total (DTMm), leaf number (LN), leaf chlorophyll index (SPAD), total chlorophyll (SFRR), nitrogen balance (NBIR), anthocyanin index (ANTHRB) and flavonoid index (FLAV).

Table 6: Plant height $(\mathrm{PH})$, stem diameter (SD), canopy diameter $(\mathrm{CaD})$, leaf number $(\mathrm{LN})$, leaf area $(\mathrm{LA})$, of "Vitória Incaper 8142" Conilon coffee seedlings.

\begin{tabular}{cccccc}
\hline Genotypes & PH $(\mathrm{m})$ & $\mathrm{SD}(\mathrm{m})$ & $\mathrm{CaD}(\mathrm{m})$ & $\mathrm{LN}$ & $\mathrm{LA}\left(\mathrm{m}^{2}\right)$ \\
\hline V1 & $0.15 \mathrm{~b}$ & $3.92 \mathrm{e}^{-3} \mathrm{~b}$ & $0.21 \mathrm{a}$ & $11.44 \mathrm{a}$ & $2.80 \mathrm{e}^{-2} \mathrm{a}$ \\
V2 & $0.19 \mathrm{a}$ & $4.27 \mathrm{e}^{-3} \mathrm{~b}$ & $0.22 \mathrm{a}$ & $09.68 \mathrm{a}$ & $2.46 \mathrm{e}^{-2} \mathrm{a}$ \\
V4 & $0.17 \mathrm{~b}$ & $3.88 \mathrm{e}^{-3} \mathrm{~b}$ & $0.23 \mathrm{a}$ & $09.54 \mathrm{a}$ & $2.75 \mathrm{e}^{-2} \mathrm{a}$ \\
V5 & $0.16 \mathrm{~b}$ & $3.96 \mathrm{e}^{-3} \mathrm{~b}$ & $0.20 \mathrm{a}$ & $08.75 \mathrm{a}$ & $2.57 \mathrm{e}^{-2} \mathrm{a}$ \\
V6 & $0.17 \mathrm{~b}$ & $4.17 \mathrm{e}^{-3} \mathrm{~b}$ & $0.21 \mathrm{a}$ & $10.86 \mathrm{a}$ & $3.02 \mathrm{e}^{-2} \mathrm{a}$ \\
V7 & $0.17 \mathrm{a}$ & $3.71 \mathrm{e}^{-3} \mathrm{~b}$ & $0.17 \mathrm{~b}$ & $08.07 \mathrm{a}$ & $1.88 \mathrm{e}^{-2} \mathrm{~b}$ \\
V8 & $0.19 \mathrm{a}$ & $4.92 \mathrm{e}^{-3} \mathrm{a}$ & $0.19 \mathrm{~b}$ & $10.04 \mathrm{a}$ & $2.77 \mathrm{e}^{-2} \mathrm{a}$ \\
V9 & $0.15 \mathrm{~b}$ & $4.04 \mathrm{e}^{-3} \mathrm{~b}$ & $0.16 \mathrm{~b}$ & $10.00 \mathrm{a}$ & $1.95 \mathrm{e}^{-2} \mathrm{~b}$ \\
V10 & $0.20 \mathrm{a}$ & $4.27 \mathrm{e}^{-3} \mathrm{~b}$ & $0.22 \mathrm{a}$ & $09.95 \mathrm{a}$ & $3.01 \mathrm{e}^{-2} \mathrm{a}$ \\
V11 & $0.18 \mathrm{a}$ & $4.00 \mathrm{e}^{-3} \mathrm{~b}$ & $0.22 \mathrm{a}$ & $10.94 \mathrm{a}$ & $2.76 \mathrm{e}^{-2} \mathrm{a}$ \\
V12 & $0.16 \mathrm{~b}$ & $4.08 \mathrm{e}^{-3} \mathrm{~b}$ & $0.18 \mathrm{~b}$ & $09.77 \mathrm{a}$ & $2.49 \mathrm{e}^{-2} \mathrm{a}$ \\
V13 & $0.17 \mathrm{~b}$ & $3.80 \mathrm{e}^{-3} \mathrm{~b}$ & $0.19 \mathrm{~b}$ & $08.76 \mathrm{a}$ & $2.56 \mathrm{e}^{-2} \mathrm{a}$ \\
\hline
\end{tabular}

Means followed by the same letter in the column are not different from each other at $5 \%$ probability level $(p<0.05)$ by the Scott-Knott test. 
Regarding the canopy diameter (Table 6), the genotypes V7, V8, V9, V12 and V13 obtained the lowest averages. The smallest canopy diameter the genotypes V7 and V9 occurred along with by a smaller leaf area. However, for the others, the smaller canopy diameter may indicate more closed canopies, which mainly affects the distribution of solar radiation among the leaves. Although genotypes V7 and V9 had a smaller leaf area, they did not differ from the others in terms of leaf number, indicating smaller leaves.

For the DQI and dry matter mass of the shoot, root and total (Table 7), the genotypes are divided into two groups, one superior to the other. Regarding DQI, the genotypes V7, V9, V12 and V13 comprised the lowest average group, and were at least $6 \%$ lower than any other genotype evaluated. It is important to observe that this index is based on the balance of biomass accumulated throughout the plant, and the higher the index, the greater the chance of success for the seedling in the field.

Table 7: Dry shoot matter mass (DSMm), root (DRMm) and total $(\mathrm{DTM})$, Dickson quality index (DQI) and chlorophyll index (SPAD) of variety "Vitória Incaper 8142" Conilon coffee seedlings.

\begin{tabular}{cccccc}
\hline Genotypes & $\begin{array}{c}\text { DSM } m \\
(\mathrm{~kg})\end{array}$ & $\begin{array}{c}\text { DRM } m \\
(\mathrm{~kg})\end{array}$ & $\begin{array}{c}\text { DTM } m \\
(\mathrm{~kg})\end{array}$ & DQI & SPAD \\
\hline V1 & $4.28 \mathrm{e}^{-3} \mathrm{a}$ & $8.50 \mathrm{e}^{-4} \mathrm{a}$ & $5.13 \mathrm{e}^{-3} \mathrm{a}$ & $0.58 \mathrm{a}$ & $29.28 \mathrm{c}$ \\
V2 & $4.02 \mathrm{e}^{-3} \mathrm{a}$ & $1.00 \mathrm{e}^{-3} \mathrm{a}$ & $5.02 \mathrm{e}^{-3} \mathrm{a}$ & $0.59 \mathrm{a}$ & $30.35 \mathrm{c}$ \\
V4 & $4.14 \mathrm{e}^{-3} \mathrm{a}$ & $9.10 \mathrm{e}^{-4} \mathrm{a}$ & $5.06 \mathrm{e}^{-3} \mathrm{a}$ & $0.59 \mathrm{a}$ & $31.24 \mathrm{c}$ \\
V5 & $3.61 \mathrm{e}^{-3} \mathrm{~b}$ & $7.60 \mathrm{e}^{-4} \mathrm{~b}$ & $4.38 \mathrm{e}^{-3} \mathrm{~b}$ & $0.50 \mathrm{a}$ & $29.94 \mathrm{c}$ \\
V6 & $3.95 \mathrm{e}^{-3} \mathrm{a}$ & $7.80 \mathrm{e}^{-4} \mathrm{~b}$ & $4.78 \mathrm{e}^{-3} \mathrm{a}$ & $0.53 \mathrm{a}$ & $30.91 \mathrm{c}$ \\
V7 & $2.83 \mathrm{e}^{-3} \mathrm{~b}$ & $5.70 \mathrm{e}^{-4} \mathrm{~b}$ & $3.40 \mathrm{e}^{-3} \mathrm{~b}$ & $0.35 \mathrm{~b}$ & $35.45 \mathrm{~b}$ \\
V8 & $5.06 \mathrm{e}^{-3} \mathrm{a}$ & $9.80 \mathrm{e}^{-4} \mathrm{a}$ & $6.04 \mathrm{e}^{-3} \mathrm{a}$ & $0.62 \mathrm{a}$ & $33.30 \mathrm{~b}$ \\
V9 & $2.95 \mathrm{e}^{-3} \mathrm{~b}$ & $5.70 \mathrm{e}^{-4} \mathrm{~b}$ & $3.42 \mathrm{e}^{-3} \mathrm{~b}$ & $0.37 \mathrm{~b}$ & $41.37 \mathrm{a}$ \\
V10 & $4.72 \mathrm{e}^{-3} \mathrm{a}$ & $9.80 \mathrm{e}^{-4} \mathrm{a}$ & $5.71 \mathrm{e}^{-3} \mathrm{a}$ & $0.58 \mathrm{a}$ & $30.89 \mathrm{c}$ \\
V11 & $3.82 \mathrm{e}^{-3} \mathrm{a}$ & $9.70 \mathrm{e}^{-4} \mathrm{a}$ & $4.79 \mathrm{e}^{-3} \mathrm{a}$ & $0.56 \mathrm{a}$ & $40.93 \mathrm{a}$ \\
V12 & $3.35 \mathrm{e}^{-3} \mathrm{~b}$ & $7.20 \mathrm{e}^{-4} \mathrm{~b}$ & $4.07 \mathrm{e}^{-3} \mathrm{~b}$ & $0.47 \mathrm{~b}$ & $34.41 \mathrm{~b}$ \\
V13 & $3.59 \mathrm{e}^{-3} \mathrm{~b}$ & $6.60 \mathrm{e}^{-4} \mathrm{~b}$ & $4.24 \mathrm{e}^{-3} \mathrm{~b}$ & $0.42 \mathrm{~b}$ & $32.96 \mathrm{~b}$
\end{tabular}

Means followed by the same letter in the column are not different from each other at the $5 \%$ probability level $(p<0.05)$ by the test of ScottKnott.

The genotypes V7 and V9 were the ones that reached the highest values in the SPAD index (Table 7). As seen in Table 6, the V9 genotype had a smaller leaf size, as it obtained a smaller leaf area for the same leaf number as the other genotypes. Thus, these results raise the hypothesis that the highest SPAD index was achieved, due to the concentration of chlorophyll molecules, in a smaller leaf area, due to the concentration effect. Similar results are found by Salamanca-Jimenez, Doane and Horwath (2016) in arabica coffee seedlings under different conditions of nitrogen availability and soil moisture, in which the highest values of chlorophyll content and SPAD index were found as the total leaf area of the plant decreased. However, according to the cited authors, the total chlorophyll amount was reduced in plants with the smallest leaf area, thus indicating that on a mass basis the plants with the largest leaf area obtained higher amounts of chlorophylls. This does not occur for the V11 genotype because it belongs to the group with the largest leaf area (Table 6), that is, it has larger leaves, which together with the highest SPAD index, provides greater photosynthetic capacity for this genotype, this being a genetic trait.

The chlorophyll index obtained through the multiplex (Table 8) got a different behavior from the SPAD index (Table 7), characterizing the difference in the sensitivity of obtaining the indexes by the two devices to assess chlorophyll. Nevertheless, a positive correlation was observed between the two variables (Figure 1), since both are indirect chlorophyll meters. A difference was detected between the genotypes for the nitrogen balance and the index of secondary metabolites, flavonoids and anthocyanins. Regarding the flavonoid index, the genotypes V1 and V6 stand out with the highest production of this metabolite, which may be an indication of greater chances of survival of these plants under stressful conditions. Addition to acting as an antioxidant agent, these metabolites also play a key role in the modulation of cell signaling survival pathways (Mansuri et al., 2014).

Table 8: Total chlorophyll (SFRR), flavonoids (FLAV), nitrogen balance (NBIR) and anthocyanins (ANTHRB) obtained through the Multiplex ${ }^{\circledR}$ equipment, in variety "Vitória Incaper 8142" conilon coffee seedlings.

\begin{tabular}{ccccc}
\hline Genotypes & SFRR & FLAV & NBIR & ANTHRB \\
\hline V1 & $2.69 \mathrm{a}$ & $0.40 \mathrm{a}$ & $1.93 \mathrm{c}$ & $0.026 \mathrm{~b}$ \\
V2 & $2.67 \mathrm{a}$ & $0.32 \mathrm{~b}$ & $2.18 \mathrm{~b}$ & $0.040 \mathrm{a}$ \\
V4 & $2.68 \mathrm{a}$ & $0.24 \mathrm{c}$ & $2.38 \mathrm{~b}$ & $0.031 \mathrm{~b}$ \\
V5 & $2.78 \mathrm{a}$ & $0.31 \mathrm{~b}$ & $2.77 \mathrm{a}$ & $0.026 \mathrm{~b}$ \\
V6 & $2.68 \mathrm{a}$ & $0.41 \mathrm{a}$ & $1.66 \mathrm{c}$ & $0.020 \mathrm{~b}$ \\
V7 & $2.94 \mathrm{a}$ & $0.16 \mathrm{c}$ & $2.96 \mathrm{a}$ & $0.032 \mathrm{~b}$ \\
V8 & $2.94 \mathrm{a}$ & $0.21 \mathrm{c}$ & $3.13 \mathrm{a}$ & $0.022 \mathrm{~b}$ \\
V9 & $3.26 \mathrm{a}$ & $0.14 \mathrm{c}$ & $2.84 \mathrm{a}$ & $0.036 \mathrm{a}$ \\
V10 & $2.70 \mathrm{a}$ & $0.35 \mathrm{~b}$ & $2.98 \mathrm{a}$ & $0.045 \mathrm{a}$ \\
V11 & $3.10 \mathrm{a}$ & $0.16 \mathrm{c}$ & $3.01 \mathrm{a}$ & $0.045 \mathrm{a}$ \\
V12 & $2.96 \mathrm{a}$ & $0.19 \mathrm{c}$ & $2.48 \mathrm{~b}$ & $0.028 \mathrm{~b}$ \\
V13 & $2.72 \mathrm{a}$ & $0.30 \mathrm{~b}$ & $2.54 \mathrm{~b}$ & $0.026 \mathrm{~b}$
\end{tabular}

Means followed by the same letter in the column are not different from each other at the $5 \%$ probability level $(p<0.05)$ by the Scott-Knott test.

The highest production of anthocyanins was observed in genotypes V2, V9, V10 and V11. Because this metabolite belongs to the flavonoid class, it has protective functions 
against stress such as water deficit, salinity, excess of UV radiation, attack of pathogens, among others (Li et al., 2016). Therefore, it is possible that the genotypes V2, V9, V10 and V11, are more likely to survive under stress conditions, as their genetic characteristics provide greater anthocyanin production.

In general, the greater synthesis of polyphenols did not negatively affect the dry total matter gain of genotypes V1, V2, V6, V9, V10 and V11 indicating that the normal growth of the seedling was maintained even with the greater investment in secondary metabolites. This can be confirmed by the low correlation between dry total matter and anthocyanins index and flavonoid index, with respective values of $r=0.24$ and 0.26 (Figure 1). This reveals that, in this case, there was no competition of nitrogen for the routes of polyphenols and proteins, but that the nitrogen was supplied in sufficient amount to maintain the two metabolic routes, in which the greater synthesis of flavonoids is an intrinsic characteristic of these genotypes.

When the data were correlated (Pearson correlation) to verify the existence of association between the variables, interesting results were observed (Figure 1). Although many of the coefficients of the correlations evaluated were significant $(p<0.01$ and $p<0.05)$, few were of medium or high magnitude. This can be attributed to the genetic diversity between the genotypes, if this analysis were carried out with only one genotype, we would possibly have higher correlation coefficients (Emerenciano Neto et al., 2019).

The SPAD showed positive correlation only with o with chlorophyll index $(r=0.45)$ and nitrogen balance $(r$ $=0.60$ ) (Figure 1). For SPAD and SFRR, this is related to the fact that both are indirect and non-destructive measures of chlorophyll. As for the nitrogen balance (NBIR) with SPAD, this is largely due to the $\mathrm{N}$ present in the chlorophyll molecules, strongly linking the chlorophyll content of the leaves to the plant's nitrogen status. Positive correlations between the chlorophyll content extracted from the leaves of the plants with the SPAD, SFRR and NBIR index have already been observed by other authors (Coelho et al., 2012; Sales et al., 2018c).

The dry total matter mass was negatively correlated with the SPAD index and the total chlorophyll SFRR, $r=$ -0.25 and -0.30 , respectively (Fgure 1). Likewise, the leaf area showed a negative correlation with the total chlorophyll SFRR $(\mathrm{r}=-0.35)$. Possibly these results were achieved due to the dilution effect that occurs between the chlorophyll molecules and dry matter mass and between leaf expansion with these same pigments.

In general, this study showed lower results for the growth characteristics of plants grown on substrates with tannery sludge. This can be attributed both to the toxic elements and to the lower availability of $\mathrm{P}$ and $\mathrm{K}$ contained in the tannery residue. It is worth mentioning that conventional treatment received an additional $0.625 \mathrm{~kg}$ of $\mathrm{P}_{2} \mathrm{O}_{5}$ and $0.200 \mathrm{~kg}$ of $\mathrm{KCl}$ for each $100 \mathrm{~L}$ of substrate, contributing to the growth of the plants.

In addition, it was possible to discover that the response pattern of the genotypes was not influenced by the substrate used. Therefore, genotypes behave similarly when using different substrates, and that the greater or lesser response between genotypes is an intrinsic characteristic of the genetic material, and not the type of substrate used.

\section{CONCLUSIONS}

The substrate containing tannery sludge provided less gain for most of the growth characteristics when compared to the conventional substrate; however, it did not differ in terms of seedling quality.

A greater synthesis of flavonoids and a lower nitrogen balance in plants grown on substrates with tannery sludge in comparison to the conventional substrate.

There was great variability between the genotypes in relation to the characteristics evaluated, where the genotypes V7, V9, V12 and V13 displayed the lowest seedling quality index.

The genotypes V1 and V6 were greater synthesis of flavonoids, which is a result of the genetic characteristics inherent to the genotypes themselves.

\section{ACKNOWLEDGMENTS}

The authors would like to thank the Espírito Santo Research and Innovation Support Foundation (FAPES) and the Federal Institute of Education, Science and Technology of Espírito Santo (IFES) for their financial and institutional support for research.

\section{REFERENCES}

ALIBARDI, L.; COSSU, R. Pre-treatment of tannery sludge for sustainable landfilling. Waste Management, 52(1):202-211, 2016.

BERILLI, S. S. et al. Substrate stabilization using humus with tannery sludge in conilon coffee seedlings. Journal of Experimental Agriculture International, 21(1):1-10, 2018.

BERILLI, S. S. et al. Níveis de cromo em mudas de café conilon desenvolvidas em substrato com lodo de curtume como adubação alternativa. Coffee Science, 10(3):320328, 2015.

BERILLI, S. S. et al. Utilização de lodo de curtume como substrato alternativo para produção de mudas de café conilon. Coffee Science, 9(4):472-479, 2014. 
CARETTO, S. et al. Carbon fluxes between primary metabolism and phenolic pathway in plant tissues under stress. International Journal of Molecular Sciences, 16(11):26378-26394, 2015.

CARVALHO, T. C. et al. Germinação e desenvolvimento inicial de plântulas de soja convencional e sua derivada transgênica RR em condições de estresse salino. Ciência Rural, 42(8):1366-1371, 2012.

COELHO, F. S. et al. Avaliação do estado nutricional do nitrogênio em batateira por meio de polifenóis e clorofila na folha. Pesquisa Agropecuária Brasileira, 47(4):584$592,2012$.

\section{COMPANHIA NACIONAL DE ABASTECIMENTO -} CONAB. Acompanhamento da safra brasileira - Café. Primeiro levantamento, janeiro 2020 - safra 2019/2020: Brasília: CONAB, 2020. Available in: <https://www. conab.gov.br/info-agro/safras/cafe $>$. Access in: January 15,2020 .

CONTARATO, C. C. et al. Evaluation of the initial development of conilon coffee genótipos (Coffea canephora). Scientia Agraria, 11(1):65-71, 2010.

COVRE, A. M. et al. Crescimento e desenvolvimento inicial de genótipos de café Conilon. Revista Agro@mbiente, 7(2):193-203, 2013.

EMPRESA BRASILEIRA DE PESQUISA AGROPECUÁRIA - EMBRAPA. Sistema brasileiro de classificação de Solos. 3. ed. Rio de Janeiro: Embrapa Solos, 2013.

EMERENCIANO NETO, J. V. et al. Características estruturais e produtivas em híbridos intraespecíficos e interespecíficos de capim-elefante. Ciência Animal Brasileira, 20:1-11, e-46788, 2019.

FERRÃO, R. G. et al. Café Conilon. 2 ed. Vitória: Incaper, 2017.

GILES, J. A. D. et al. Divergence and genetic parameters between Coffea sp. genotypes based in foliar morphoanatomical traits. Scientia Horticulturae, 245(1):231236, 2019.

FERREIRA, E. B.; CAVALCANTI, P. P.; NOGUEIRA, D. A. Package 'ExpDes.pt': Pacote Experimental Designs (Portuguese). R package version 1.1.2. 2013.

\section{INSTITUTO CAPIXABA DE PESQUISA ASSISTENCIA} TÉCNICA E EXTENSÃO RURAL - INCAPER. Cafeicultura - Tecnologias. 2019. Available in: $<$ https:// incaper.es.gov.br/cafeicultura-tecnologias $>$. Access in: March 2, 2019.
INTERNETINAL COFFEE ORGANIZATION ICO. Relatório sobre o mercado de Café. Available in: http://www.ico.org/documents/cy2019-20/cmr-1019-p. pdf $>$. Access in: March 2, 2019.

KARASAWA, S. et al. Desenvolvimento de mudas de cafeeiro (Coffea arábica L.) irrigados com água salina. Engenharia Rural, 14(1):1-12, 2003.

KHALID, M. et al. Role of flavonoids in plant interactions with the environment and against human pathogens - A review. Journal of Integrative Agriculture, 18(1):211230, 2019.

LI, P. The Arabidopsis UDP-glycosyltransferases UGT79B2 and UGT79B3, contribute to cold, salt and drought stress tolerance via modulating anthocyanin accumulation. The Plant Journal, 89(1):85-103, 2016.

MANSURI, M. L. et al. Flavonoids in modulation of cell survival signalling pathways. Genes \& Nutrition, 9(3):19, 2014.

MARSCHNER, H. Mineral nutrition of higher plants. New York: Academic Press, 2011.

MENEGHELLI, C. M. et al. Waste of drying coffee beans as a substrate alternative in coffee conilon seedlings. Coffee Science, 11(3):329-334, 2016.

QUARTEZANI, W. Z. et al. Effect of different proportions of urban organic compost on conilon coffee ('Coffea canephora') propagation. Australian Journal of Crop Science, 13(6):821, 2019

QUARTEZANI, W. Z. et al. Conilon plant growth response to sources of organic matter. African Journal of Agricultural Research, 13(4):181-188, 2018.

R CORE TEAM. R: A Language and Environment for Statistical Computing. 2016. Available in: $<$ https:// www.r-project.org/>. Access in: March 2, 2019.

SALAMANCA-JIMENEZ, A.; DOANE, T. A.; HORWATH, W. R. Performance of coffee seedlings as affected by soil moisture and nitrogen application. Advances in Agronomy, 136(1):221-244, 2016.

SALES, R. A. et al. Foliar fertilization using liquid tannery sludge in conilon coffee seedlings production. Journal of Experimental Agriculture International, 22(2):1-8, 2018a.

SALES, R. A. et al. Sazonal and interanual rainfall variability for Colatina, Espirito Santo, Brazil. Scientia Agraria, 19(2):186-196, $2018 \mathrm{~b}$. 
SALES, R. A. et al. Influência de diferentes fontes de matéria orgânica em componentes fisiológicos de folhas da espécie Schinus terebinthifolius Raddi. (Anacardiaceae). Scientia Agraria, 19(1):132-141, 2018c.

SILVA, J. D. C. et al. Effect of different tannery sludge compost amendment rates on growth, biomass accumulation and yield responses of Capsicum plants. Waste Manage, 30(1):1976-1980, 2010a.

SILVA, L. D. et al. Fotossíntese, relações hídricas e crescimento de cafeeiros jovens em relação à disponibilidade de fósforo. Pesquisa Agropecuária Brasileira, 45(9):965-972, $2010 \mathrm{~b}$.

TAVARES, L. S. et al. Lodo do curtimento e sua influência na produção de mudas de paricá (Schizolobium amazonicum) e nas propriedades químicas do solo. Ciência Florestal, 23(3):357-368, 2013.

TEMOTEO, A. S. et al. Crescimento de cultivares de cafeeiro conilon submetidas ao estresse salino-hídrico. Revista Caatinga, 28(2):46-56, 2015.

VAZIFEHKHORAN, A. H.; SHIN, S. G.; TRIOLO, J. M. Use of tannery wastewater as an alternative substrate and a pre-treatment medium for biogas production. Bioresource Technology, 258(1):64-69, 2018.

WEI, T.; SIMKO, V. Package "corrplot": Visualization of a correlation matrix. R package version 0.84, 2017.

ZAHEER, M. M. et al. Amelioration of cadmium stress in gladiolus (Gladiolus grandiflora L.) by application of potassium and silicon. Journal of Plant Nutrition, 41(4):461-476, 2018. 